\title{
A Suite of High-quality Butternut Squash
}

\author{
Rachel L. Hultengren, Lindsay Wyatt ${ }^{1}$, and Michael Mazourek ${ }^{2}$ \\ Section of Plant Breeding and Genetics, Cornell University, Ithaca, NY \\ 14853
}

Additional index words. butternut squash, Cucurbita, fruit quality, plant breeding, vegetable

Squash is a major crop for vegetable growers in the northeastern United States, with New York and New Jersey accounting for roughly $14 \%$ of the U.S. production in 2015 (USDA, 2016). Growers have identified the breeding of high-quality winter squash with powdery mildew resistance as a major priority. This was a goal of the Northern Organic Vegetable Improvement Collaborative (NOVIC), a project to evaluate and develop regionally appropriate seed for organic vegetable growers (eOrganic, 2016), and was echoed in a recently conducted needs assessment of organic vegetable growers in the Northeast (Hultengren et al., 2016).

In the United States, infection by powdery mildew (Podosphaera xanthii, syn. Sphaerotheca fuliginea) causes yield losses in squash (McCreight, 2004) due to reduced number of fruit and also causes lower fruit quality (Zitter et al., 1996). Powdery mildew can be managed through fungicide application in conventional systems, but the increased occurrence of fungicide resistance and the lack of options for organic systems highlight the continued need for host resistance as a priority trait in breeding programs (Pérez-García et al., 2009).

'Honeynut' is a miniature butternut with exceptional color, high percent soluble solids, and high percent dry matter, which make it

Received for publication 31 May 2016. Accepted for publication 18 Aug. 2016.

This research was supported by the National Institute of Food and Agriculture, U.S. Department of Agriculture Organic Agriculture Research and Extension Initiative Project No. 2009-51300-05585 and Agriculture and Food Research Initiative Project No. 2013-67013-21232, and the David Rockefeller Fund. Support for Lindsay Wyatt was provided by a Cornell University Presidential Life Sciences Fellowship, USDA National Needs Graduate Fellowship Competitive Grant No. 2008-38420-04755 from the National Institute of Food and Agriculture, and the Agriculture and Food Research Initiative Competitive Grant No. 2013-67011-21122 from the USDA National Institute of Food and Agriculture. We thank Molly Jahn, Martha Munger, and Nancy Munger for their support in honor of the legacy of vegetable breeding at Cornell.

Any opinions, findings, conclusions, or recommendations expressed in the publication are those of the author(s) and do not necessarily reflect the view of the U.S. Department of Agriculture (USDA).

${ }^{1}$ Current address: Johnny's Selected Seeds, 955 Benton Avenue, Winslow, ME 04901.

${ }^{2}$ Corresponding author. E-mail: mm284@cornell.edu. a sweet squash with good texture in a convenient size for consumers. It has become highly popular among consumers and growers (Barber, 2014) and represents a novel type of squash that has been prioritized by growers for future cultivar development, specifically through enhancing the powdery mildew resistance in a 'Honeynut'-type squash.

In this study, we evaluated the yield, disease resistance, and fruit quality characteristics of new small butternut squash from our breeding program that combine 'Honeynut' and 'Bugle' (a powdery mildew resistant butternut) in their pedigrees. These new squash were compared with their two parents and 'Waltham', a commercial standard butternut squash, under both conventional and organic management systems.

\section{Materials and Methods}

Germplasm evaluated. 'Honeynut' is a highquality miniature butternut developed at Cornell University. It is a pureline cultivar derived from a cross between butternut (Cucurbita moschata) and buttercup (Cucurbita maxima) and selected to be self-fertile (Robinson, Jahn, and Mazourek, unpublished data). 'Bugle' is a diseaseresistant butternut developed by Munger and Jahn at Cornell University that contains the $\mathrm{Pm}$-0 gene introgressed from Cucurbita okeechobeensis (Contin, 1978), which confers high levels of resistance to powdery mildew (Cohen et al., 2003; Paris and Brown, 2005). 'Honeynut' and 'Bugle' were crossed to produce the hybrid 'Amber Delight'. Six to eight rounds of self-pollination and selection for powdery mildew resistance and fruit quality traits yielded a suite of pureline butternuts (referred to here as HQBN1-5). 'Waltham' was originally obtained from Harris Seed.

Field site. Butternut seedlings were sown 13 May 2014 in the Guterman Greenhouse on Cornell University campus, using Cornell PeatLite (GreenTree, Ithaca, NY) for the conventional trial and Fort Lite (Vermont Compost Company, Montpelier, VT) for the organic trial. After germination, seedlings were transferred to a coldframe on 28 May 2014 to harden off. Seedlings under conventional management were treated with imidacloprid (Marathon ${ }^{\circledR}$, Bayer Environmental Science, Research Triangle Park, NC) to control striped cucumber beetle, and were transplanted 10 June 2014 on the Homer C. Thompson Vegetable Research Farm (Freeville, NY). Seedlings under organic management were transplanted 12 June 2014 at the Freeville Organic Research Farm
(Freeville, NY). Seedlings were transplanted into raised beds with drip tape and black plastic mulch, 10 plants per plot at $3.7 \mathrm{~m}$ between rows and $0.6 \mathrm{~m}$ between plants in a three-replicate randomized complete block design. Row cover (Agribon ${ }^{\circledR}$, San Luis Potosí, Mexico) was placed over both sets of seedlings at transplanting to protect against insect pests and inclement weather and was removed on 7 July 2014 to allow for pollination.

Yield trial harvest. Mature fruit were harvested at the end of the season. At harvest, the stand count of each plot was noted and all marketable fruit were harvested and cured for 1 month. All marketable fruit from each plot were counted and weighed. These fruit were placed in storage to be later assessed for fruit quality.

Disease-resistance evaluation. Given the dependable occurrence of powdery mildew in upstate New York, plants were exposed to natural inoculum in the field as the source of the pathogen, as has been done for decades in our breeding program. All lines were evaluated for powdery mildew severity once during the season, on 14 Sept. 2014. Percent leaf coverage of powdery mildew was rated on a plot basis, $0 \%$ to $100 \%$.

Fruit characteristics. After 1 month of storage following harvest and curing, 10 marketable fruit per plot were selected at random for fruit quality measurements. Individual fruit size attributes (length, width at widest point, and weight) were recorded before samples of mesocarp tissue were taken for other measurements. Percent soluble solids and percent dry matter were measured; $\mathrm{L}^{*}$ and $\mathrm{a}^{*}$ color space values were measured using a Konica Minolta CR-400 Chroma Meter (Konica Minolta Sensing Americas Inc., Ramsey, NJ).

Statistical analysis. The trial data were analyzed in JMP Pro 11.0.0 (JMP ${ }^{\circledR}$, Version 11. SAS Institute Inc., Cary, NC, 19892007), using one-way analysis of variance. For all analyses with a $P$ value $<0.05$, means and SD were calculated, and all pairwise comparisons were made using the TukeyKramer method to generate the connecting letters reports included herein.

\section{Results and Discussion}

\section{Agronomic traits}

Disease resistance. All of the breeding material evaluated had less severe powdery mildew than the industry standard 'Waltham' $(70.0 \% \pm 11.0 \%)$ (Table 1). 'Bugle' had the lowest percent powdery mildew $(18.3 \% \pm$ $7.5 \%$ ), as was expected for the source of resistance for the breeding lines. The severity of powdery mildew on the 'Amber Delight' hybrid, as well as on two of the purelines, was not significantly higher than the severity measured for 'Bugle'; powdery mildew on the other breeding lines was no more severe than on 'Honeynut', which is reported to have moderate field resistance (High Mowing Organic Seed, 2016). The reduction of powdery mildew severity can lead to heavier, higher quality fruit (as plants accumulate sugars for a longer period in the field while leaves are still green) with potential for better 
Table 1. Agronomic traits of 'Honeynut', 'Bugle', 'Amber Delight' ('Honeynut' $\times$ 'Bugle' $\mathrm{F}_{1}$ ), five pure-breeding lines derived from that $\mathrm{F}_{1}$, and 'Waltham' evaluated under conventional and organic management.

\begin{tabular}{lcc}
\hline Pedigree & Powdery mildew $(\%)$ & Yield (fruit/plant) \\
'Honeynut' & $46.0 \pm 11.4 \mathrm{~b}^{\mathrm{y}}$ & $3.2 \pm 0.6 \mathrm{ab}$ \\
'Bugle' & $18.3 \pm 7.5 \mathrm{c}$ & $3.5 \pm 0.6 \mathrm{ab}$ \\
'Amber Delight' & $28.3 \pm 11.7 \mathrm{bc}$ & $3.5 \pm 0.9 \mathrm{ab}$ \\
HQBN1 & $38.3 \pm 4.1 \mathrm{~b}$ & $2.6 \pm 0.5 \mathrm{bc}$ \\
HQBN2 & $41.7 \pm 7.5 \mathrm{~b}$ & $2.9 \pm 1.0 \mathrm{~b}$ \\
HQBN3 & $41.7 \pm 13.7 \mathrm{~b}$ & $2.5 \pm 0.6 \mathrm{~b}$ \\
HQBN4 & $33.3 \pm 5.2 \mathrm{bc}$ & $5.0 \pm 1.6 \mathrm{a}$ \\
HQBN5 & $20.0 \pm 6.3 \mathrm{c}$ & $3.8 \pm 0.7 \mathrm{ab}$ \\
'Waltham' & $70.0 \pm 11.0 \mathrm{a}$ & $3.7 \pm 1.0 \mathrm{ab}$ \\
\hline
\end{tabular}

${ }^{\mathrm{z}}$ Percentage of leaf area coverage by fungal spores.

${ }^{\mathrm{y}}$ Entries whose means and sDs are followed by the same letter are not significantly different at $P \leq 0.05$.

Table 2. Fruit quality of 'Honeynut', 'Bugle', 'Amber Delight' ('Honeynut' $\times$ 'Bugle' $\mathrm{F}_{1}$ ), five pure-breeding lines derived from that $\mathrm{F}_{1}$, and 'Waltham' evaluated under conventional and organic management.

\begin{tabular}{|c|c|c|c|c|}
\hline$\overline{\text { Pedigree }}$ & Soluble solids (\%) & Dry matter $(\%)$ & $\mathrm{L}^{*}$ & $\overline{a *}$ \\
\hline 'Honeynut' & $12.9 \pm 1.5 \mathrm{a}^{\mathrm{z}}$ & $15.5 \pm 1.7 \mathrm{a}$ & $70.2 \pm 1.4 \mathrm{de}$ & $30.8 \pm 2.2 \mathrm{a}$ \\
\hline 'Bugle' & $10.1 \pm 1.0 \mathrm{e}$ & $13.1 \pm 1.7 \mathrm{~d}$ & $76.6 \pm 2.7 \mathrm{a}$ & $23.6 \pm 2.5 \mathrm{e}$ \\
\hline 'Amber Delight' & $11.9 \pm 1.2 \mathrm{bc}$ & $15.2 \pm 1.6 \mathrm{ab}$ & $70.6 \pm 2.1 \mathrm{de}$ & $29.3 \pm 2.2 \mathrm{~b}$ \\
\hline HQBN1 & $12.6 \pm 1.4 \mathrm{ab}$ & $14.9 \pm 1.8 \mathrm{ab}$ & $71.3 \pm 1.7 \mathrm{~cd}$ & $29.8 \pm 2.4 \mathrm{ab}$ \\
\hline HQBN2 & $12.3 \pm 1.3 \mathrm{abc}$ & $15.2 \pm 2.2 \mathrm{ab}$ & $71.9 \pm 2.2 \mathrm{c}$ & $27.4 \pm 2.7 \mathrm{c}$ \\
\hline HQBN3 & $11.7 \pm 1.2 \mathrm{~cd}$ & $14.1 \pm 1.9 \mathrm{bcd}$ & $72.3 \pm 1.9 \mathrm{c}$ & $25.2 \pm 2.2 \mathrm{~d}$ \\
\hline HQBN4 & $11.7 \pm 1.0 \mathrm{~cd}$ & $14.2 \pm 1.6 \mathrm{bc}$ & $69.7 \pm 1.6 \mathrm{e}$ & $30.4 \pm 1.6 \mathrm{ab}$ \\
\hline HQBN5 & $11.1 \pm 1.1 \mathrm{~d}$ & $13.7 \pm 1.7 \mathrm{~cd}$ & $70.5 \pm 2.3 \mathrm{de}$ & $29.9 \pm 2.4 \mathrm{ab}$ \\
\hline 'Waltham' & $9.5 \pm 1.5 \mathrm{e}$ & $11.1 \pm 2.0 \mathrm{e}$ & $73.8 \pm 2.5 b$ & $25.2 \pm 2.9 \mathrm{~d}$ \\
\hline
\end{tabular}

${ }^{\mathrm{z}}$ Entries whose means and sDs are followed by the same letter are not significantly different at $P \leq 0.05$.

storage (Jahn et al., 2002). Through the 2015 Organic Vegetable Breeding Needs Assessment survey (in which northeastern organic vegetable growers were asked to rate the importance of plant traits and indicate their priority as breeding objectives), $89 \%$ of growers (93 of 105) agreed that genetic resistance to powdery mildew in cucurbits was important, and $39 \%$ of growers (40 of 105 ) indicated that such resistance should be considered a high breeding priority (Hultengren et al., 2016). Our breeding efforts have captured this disease resistance in these new lines, which will be particularly important for organic growers, whose options for chemical disease management tend to be limited. Genetically resistant cultivars are also needed by conventional growers, whose options are increasingly limited by the pathogen's development of fungicide resistance (McGrath, 2011).

Yield. 'Honeynut, 'Bugle', and 'Amber Delight' had the same fruit per plant yield as industry standard 'Waltham' (Table 1). One of the inbred lines (HQBN3) had significantly higher fruit per plant yield than 'Waltham'; the rest did not differ significantly from 'Waltham' or their 'Honeynut' and 'Bugle' parents.

'Amber Delight' and 'Waltham' had the highest yield per plant by weight $(2.9 \pm 1.0 \mathrm{~kg}$ and $2.9 \pm 0.4 \mathrm{~kg}$, respectively). The yield by weight per plant of 'Bugle' and breeding lines HQBN3 and HQBN5 did not differ significantly from that of Waltham. The yield by weight of the rest of the breeding lines was at least as high as that of 'Honeynut' $(1.5 \pm 0.5 \mathrm{~kg})$.

\section{Fruit quality}

Percent soluble solids. 'Honeynut', which was selected for sweetness, had the highest

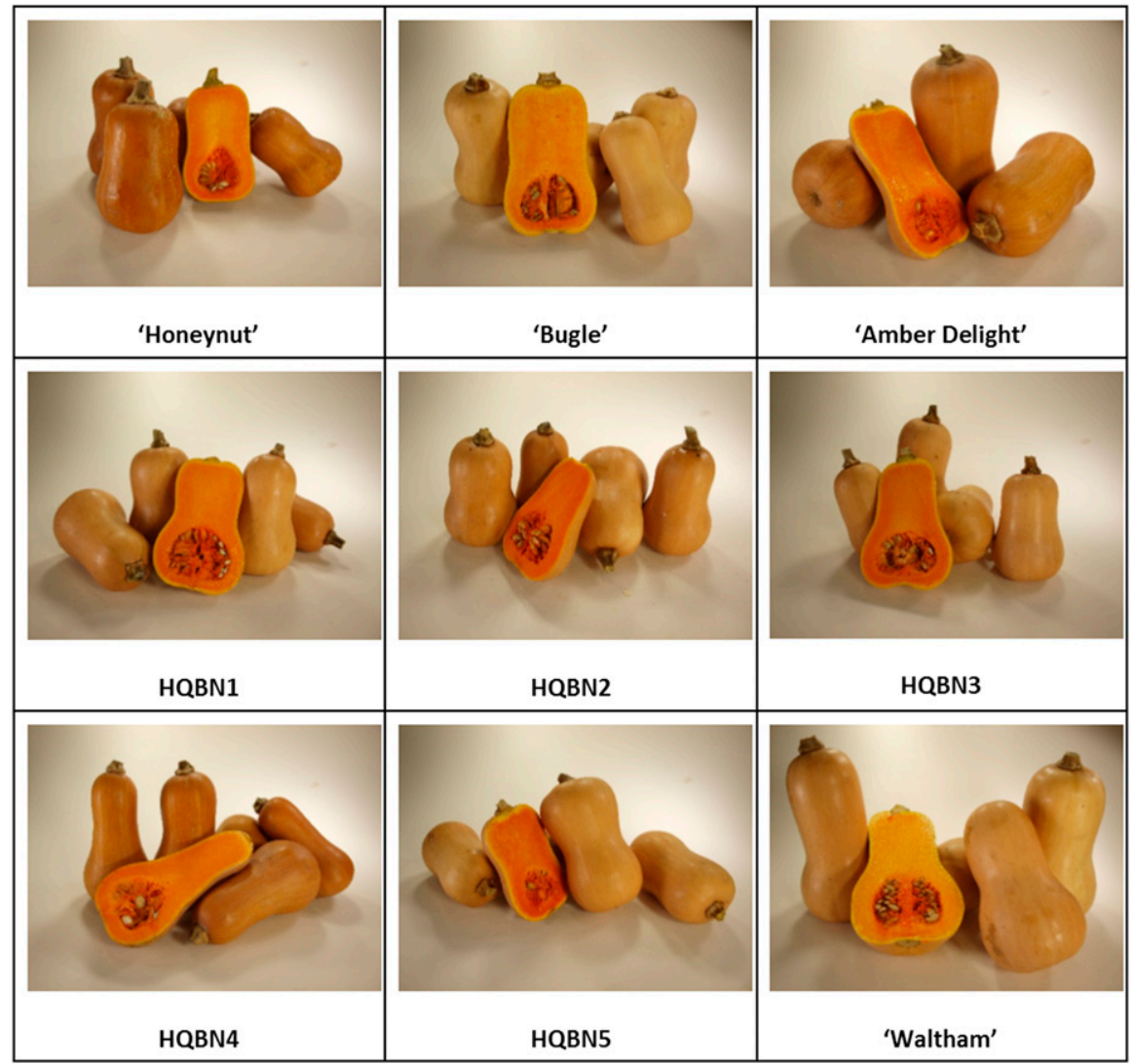

Fig. 1. Photographs of representative fruit of 'Honeynut', 'Bugle', 'Amber Delight' ('Honeynut' $\times$ 'Bugle' $\mathrm{F}_{1}$ ), five pure-breeding lines derived from that $\mathrm{F}_{1}$, and 'Waltham'.

percent soluble solids of all lines in these trials $(12.9 \% \pm 1.5 \%)$ (Table 2). The new purelines had percent soluble solids higher than that of both 'Waltham' and 'Bugle, with some as high as that of 'Honeynut'. Percent soluble solids for 'Amber Delight' was intermediate between its 'Honeynut' and 'Bugle' parents.

Dry matter. 'Honeynut', 'Bugle', 'Amber Delight' and all of the breeding lines had significantly higher percent dry matter than 
Table 3. Fruit measurements of 'Honeynut', 'Bugle', 'Amber Delight' ('Honeynut' $\times$ 'Bugle' $\mathrm{F}_{1}$ ), five pure-breeding lines derived from that $\mathrm{F}_{1}$, and 'Waltham' evaluated under conventional and organic management.

\begin{tabular}{lccc}
\hline Pedigree & Fruit length $(\mathrm{cm})$ & Fruit width $(\mathrm{cm})$ & Fruit wt $(\mathrm{kg})$ \\
'Honeynut' & $13.1 \pm 1.3 \mathrm{e}^{\mathrm{z}}$ & $8.6 \pm 0.9 \mathrm{~d}$ & $0.5 \pm 0.1 \mathrm{de}$ \\
'Bugle' & $15.6 \pm 1.7 \mathrm{bc}$ & $9.5 \pm 0.8 \mathrm{~b}$ & $0.7 \pm 0.2 \mathrm{~b}$ \\
'Amber Delight' & $16.1 \pm 1.8 \mathrm{~b}$ & $9.6 \pm 1.1 \mathrm{~b}$ & $0.8 \pm 0.3 \mathrm{~b}$ \\
HQBN1 & $13.6 \pm 1.7 \mathrm{de}$ & $8.7 \pm 0.9 \mathrm{~d}$ & $0.5 \pm 0.2 \mathrm{de}$ \\
HQBN2 & $14.1 \pm 1.7 \mathrm{de}$ & $8.8 \pm 0.8 \mathrm{~cd}$ & $0.5 \pm 0.1 \mathrm{cde}$ \\
HQBN3 & $15.5 \pm 1.7 \mathrm{bc}$ & $9.4 \pm 1.0 \mathrm{bc}$ & $0.6 \pm 0.2 \mathrm{bc}$ \\
HQBN4 & $16.4 \pm 2.0 \mathrm{~b}$ & $8.3 \pm 0.9 \mathrm{~d}$ & $0.4 \pm 0.1 \mathrm{e}$ \\
HQBN5 & $14.6 \pm 1.7 \mathrm{~cd}$ & $8.6 \pm 1.0 \mathrm{~d}$ & $0.6 \pm 0.2 \mathrm{~cd}$ \\
'Waltham' & $20.2 \pm 2.4 \mathrm{a}$ & $12.5 \pm 1.1 \mathrm{a}$ & $1.3 \pm 0.4 \mathrm{a}$ \\
\hline
\end{tabular}

${ }^{\mathrm{z}}$ Entries whose means and SDs are followed by the same letter are not significantly different at $P \leq 0.05$.

'Waltham' (Table 2). 'Amber Delight' and two of the five breeding lines (HQBN1, and HQBN2) had percent dry matter not significantly different from that of 'Honeynut' $(15.5 \% \pm 1.7 \%)$, which was the highest of all lines in the trials.

Color space values. $\mathrm{L}^{*}$ and $\mathrm{a}^{*}$ color space values are used to describe the color of the squash fruit flesh. The $a^{*}$ value indicates the red component of the mesocarp's orange color (with higher values corresponding to more red) and the $\mathrm{L}^{*}$ value indicates the lightness of color (with low values corresponding to darker coloration) (Itle and Kabelka, 2009). A squash with a low $\mathrm{L}^{*}$ value and high a* value, therefore, has a dark orange color.

In this study, 'Honeynut' had a low L* value and high $\mathrm{a}^{*}$ value (indicating a darker, more red orange flesh); 'Bugle' had the highest $\mathrm{L}^{*}$ and lowest $\mathrm{a}^{*}$ values (indicating a lighter, less red orange flesh). In these trials, all of the new lines had L* values significantly lower than both 'Waltham' (73.8 \pm 2.5$)$ and 'Bugle' (76.6 \pm 2.7). 'Amber Delight' and several breeding lines had $\mathrm{L}^{*}$ values as low as (or lower than) that of 'Honeynut' $(70.2 \pm 1.4)$; the rest of the breeding lines had $\mathrm{L}^{*}$ values intermediate between 'Bugle' and 'Honeynut' (Table 2).

'Amber Delight' and the new purelines had a* values significantly higher than that of 'Bugle' (23.6 \pm 2.5$)$; with the exception of HQBN3, their a* values were also higher than that of 'Waltham'. Several purelines had an $a^{*}$ value not significantly different from that of 'Honeynut' $(30.8 \pm 2.2)$.

Provitamin A is an important nutrient which must be obtained through our diet. Being high in carotenoids-particularly $\alpha$ - and $\beta$-carotene (Gross, 1991)-winter squash is a good source of provitamin A. Color space values may be used to estimate carotenoid content: $\mathrm{L}^{*}$ value is negatively correlated to total carotenoid levels and $\mathrm{a}^{*}$ value is positively correlated to total carotenoids (Itle and Kabelka, 2009). 'Honeynut' has low L* and high a* values; the 'Amber Delight' hybrid also demonstrates these qualities, and the new lines show promising values. In addition to indicating nutritional quality, the color of squash fruit may contribute to its acceptability, as the appearance of food affects consumer preferences and eating experience (Hutchings, 1993). These lines are more vividly orange. In tomato, volatile carotenoid precursors have been found to impact taste experience (Vogel et al., 2010); if a similar trend exists in butternuts, these lines may also derive a taste benefit from their more intense coloration.

\section{Fruit size}

'Honeynut' fruit are small-much lighter, shorter, and narrower than 'Waltham'. 'Bugle' fruit are midsized, smaller than 'Waltham' but larger than 'Honeynut'. The fruit of the 'Amber Delight' hybrid was, on average, not significantly smaller than the fruit of 'Bugle' in any dimension. Fruit dimensions were varied among the new inbred lines (Fig. 1; Table 3).

\section{Conclusion}

These improved new varieties display exceptional qualities and there is clearly a demand for them. 'Amber Delight' was a top performer across all the traits we assessed, providing a good combination of the highquality traits of its parents, 'Honeynut' and 'Bugle', and addressing the need for a larger, high-quality, disease-resistant butternut. The butternuts with the overall highest quality were HQBN1 and HQBN2; HQBN3, and HQBN5 were the highest yielding. The new 'Honeynut' $\times$ 'Bugle' lines - high-quality mini butternuts with better disease resistance - have potential utility as either pureline cultivars or hybrid parents.

\section{Availability}

For seed requests, please contact Michael Mazourek(mm284@cornell.edu).

\section{Literature Cited}

Barber, D. 2014. "Honey, I shrunk the squash." Saveur. 11 May 2016. <http://www.saveur.com/ article/ingredients/honey-i-shrunk-the-squash>.
Cohen, R., A. Hanan, and H.S. Paris. 2003. Single-gene resistance to powdery mildew in zucchini squash (Cucurbita pepo). Euphytica 130:433-441.

Contin, M. 1978. Interspecific transfer of powdery mildew resistance in the genus Cucurbita. Cornell Univ., Ithaca, NY. PhD Diss.

eOrganic. 2016. NOVIC. Oregon State University. 18 May 2016. $<\mathrm{http}: / /$ eorganic.info/novic/>.

Gross, J. 1991. Pigments in vegetables: Chlorophylls and carotenoids. In: J. Gross (ed.).Van Nostrand Reinhold, New York, NY.

High Mowing Organic Seeds. 2016. Organic nonGMO Honeynut butternut squash. 17 Apr. 2016. $<$ http://www.highmowingseeds.com/organicnon-gmo-seeds-honey-nut-butternut-squash. html>.

Hultengren, R.L., M. Glos, and M. Mazourek. 2016. Breeding research and education needs assessment for organic vegetable growers in the northeast. eCommons Digital Repository at Cornell Univ., Ithaca, NY. 31 Aug. 2016. $<$ http://hdl.handle.net/1813/44636>.

Hutchings, J.B. 1993. Food colour and appearance. Blackie Academic \& Professional, London, UK.

Itle, R.A. and E.A. Kabelka. 2009. Correlation between $\mathrm{L}^{*} \mathrm{a}^{*} \mathrm{~b}^{*}$ color space values and carotenoid content in pumpkins and squash (Cuburbita spp.). HortScience 44:633-637.

Jahn, M., J.D. McCreight, and H.M. Munger. 2002. Breeding cucurbit crops for powdery mildew resistance, p. 239-248. In: R.R. Bélanger, W.R. Bushnell, A.J. Dik, and T.L.W. Carver (eds.). The powdery mildews: A comprehensive treatise. The Amer. Phytopathol Soc. (APS), St. Paul, MN.

McCreight, J.D. 2004. Notes on the change of the causal species of cucurbit powdery mildew. U.S. Cucurbit Genetics Cooperative Report 27:8-23.

McGrath, M.T. 2011. Challenge of fungicide resistance in managing vegetable diseases in United States and anti-resistance strategies, p. 191-207. In: T.S. Thind (ed.). Fungicide resistance in crop protection: Threat and management. CABI International, Cambridge, MA.

Paris, H.S. and R.N. Brown. 2005. The genes of pumpkin and squash. HortScience 40:1620 1630.

Pérez-García, A., D. Romero, D. FernándezOrtuño, F. López-Ruiz, A. de Vicente, and J.A. Torés. 2009. The powdery mildew fungus Podosphaera fusca (synonym Podosphaera xanthii), a constant threat to cucurbits. Mol. Plant Pathol. 10(2):153-160.

U.S. Department of Agriculture (USDA). 2016. Vegetables 2015 Summary. 18 May 2016. U.S. Dept. Agr., Washington, DC. <http://usda mannlib.cornell.edu/usda/current/VegeSumm/ VegeSumm-02-04-2016.pdf $>$.

Vogel, J.T., D.M. Tieman, C.A. Sims, A.Z. Odabasi, D.G. Clark, and H.J. Klee. 2010 Carotenoid content impacts flavor acceptability in tomato (Solanum lycopersicum). J. Sci. Food Agr. 90(13):2233-2240.

Zitter, T.A., D.L. Hopkins, and C.E. Thomas. 1996. Compendium of cucurbit diseases. The Amer. Phytopathol Soc. (APS), St. Paul, MN. 